\title{
Effects of bilateral ganglionectomy and melatonin replacement on seasonal rhythm of testicular activity in Zembra Island wild rabbits (Oryctolagus cuniculus)
}

\author{
M. M. Ben Saad ${ }^{1}$ and D. Maurel ${ }^{2 *}$ \\ ${ }^{1}$ Laboratoire de Physiologie Animale, Faculté des Sciences de Tunis, Campus Universitaire, \\ 1060 Tunis, Tunisie; and ${ }^{2}$ Pathologie de l'Oreille interne et Réhabilitation, \\ EPI 9902 INSERM, Faculté de Médecine Nord, Boulevard Pierre-Dramard, \\ 13916 Marseille cedex 20, France
}

This study examined the effects of subcutaneous melatonin implants on testicular activity (testis volume and plasma testosterone) in wild rabbits (Oryctolagus cuniculus) captured on Zembra Island (North Tunisia) and maintained in natural temperature and photoperiod conditions. The period of testicular activity was 2 months longer in intact animals with melatonin implants than in intact animals without melatonin implants. After bilateral superior cervical ganglionectomy, testicular activity was inhibited and no spontaneous recrudescence in gonadal function was observed during the 13 months of the experiment, demon- strating the absence of an endogenous circannual rhythm of reproductive function in this species. Renewed testicular activity was observed 2 months after the insertion of melatonin implants in ganglionectomized animals. These results confirm that testicular activity is stimulated by short days in late autumn and that melatonin reactivates the reproductive axis in this species. This finding is in contrast to that in continental populations of wild rabbits in which reproduction is inhibited by short days or melatonin. These results are discussed in terms of insularity and may reflect the geographical isolation of this population.

\section{Introduction}

In a previous study on the population of wild rabbits (Oryctolagus cuniculus) on Zembra Island, it was shown that testicular activity begins in late autumn (October-November) in short-day conditions (Ben Saad and Baylé, 1985) and that the seasonal increase in testicular activity is prevented by superior cervical ganglionectomy (Ben Saad, 1997). In other short-day mammals, such as sheep (Kennaway, 1984) and mink (Ravault et al., 1986; Maurel et al., 1992a), ganglionectomy, resulting in complete abolition of the diurnal melatonin rhythm, is known to inhibit the seasonal reactivation of testicular activity by short days. It is now well established that melatonin, a 5methoxyindole synthesized by the pineal gland, plays a major role in the photoperiodic control of reproduction (that is, control of testicular function throughout the year in male mammals), showing seasonality in relation to day length in the natural environment (reviewed in Reiter, 1974, 1980; Arendt, 1986; Arendt et al., 1988, Goldman, 1999). As first suggested by Hoffmann (1981), melatonin is a hormonal mediator of photoperiodic effects. It is secreted nocturnally and it is now accepted that circulating melatonin concentrations, regulated by the alternation of light and dark periods, constitute an endocrine message

*Correspondence

Email: maurel.d@jean-roche.univ-mrs.fr providing information about daily and seasonal changes in photoperiod (Goldman and Darrow, 1983; Reiter, 1986, 1988; Goldman, 1999). The morphological and functional chain linking the retina to the pineal gland has not been completely elucidated. However, it is known that information about the photoperiod is transferred from the retina to the suprachiasmatic nucleus via the retinohypothalamic tract, and reaches the pineal gland through noradrenergic fibres via the superior cervical ganglion. Experiments involving pinealectomy or deafferentation of the pineal body by bilateral superior cervical ganglionectomy have shown that the pineal gland and melatonin play primary roles in the photoregulation of reproductive activity in various mammals (Reiter, 1972; Stetson and Watson-Withmyre, 1976; Lincoln, 1979; Carter et al., 1982; Maeda et al., 1985; Boissin-Agasse et al., 1988; Maurel et al., 1990). In long-day species, the seasonal recrudescence of sexual activity occurs when day length increases; in short-day species, the shortening of the day length triggers the reproductive season. However, in both short- and long-day species, the melatonin signal corresponding to short days (increase in duration of high melatonin concentrations during the night) is the primary photoperiodic information controlling: (i) gonad atrophy in long-day species, in which renewal occurs spontaneously, or (ii) gonad renewal in short-day species, in which sexual regression is not driven directly by photoperiod (Reiter, 1986; Boissin and Canguilhem, 1988). The present study investigated the 
effects of subcutaneous melatonin pellets in intact or ganglionectomized males maintained in natural temperature and photoperiod conditions. The aim was to determine the role of melatonin in the control of reproduction in this population of wild rabbits on Zembra Island, which is considered to be a short-day species. Testicular activity was assessed by determining testis volume and plasma testosterone.

\section{Materials and Methods}

\section{Animals}

The animals were trapped on Zembra Island (30 $50 \mathrm{~N}$, $\left.10^{\circ} 14^{\prime} \mathrm{E}\right)$ in the north of Tunisia. All the animals used in this study were adult males in good condition. The experiments were performed in accordance with the European Community Council Directive (86/609/EEC). Once caught, the animals were transferred to the laboratory where they were caged individually and exposed to natural temperature and photoperiod conditions for the duration of the experiment. The animals were fed an appropriate diet (rabbit chow, SNA Tunisie) and given water ad libitum.

\section{Experimental schedule}

Twenty adult male rabbits (Oryctolagus cuniculus) were used in this study (mean body weight, $1170 \pm 60 \mathrm{~g}$ ). The animals were randomly assigned to four treatment groups, each containing five animals: (1) intact; (2) intact with subcutaneous melatonin implants; (3) ganglionectomized; and (4) ganglionectomized with subcutaneous melatonin implants. The four groups were studied over 13 months.

\section{Surgery and melatonin replacement}

Bilateral ablation of the superior cervical ganglion was conducted under deep sodium pentobarbital anaesthesia (0.4 ml kg-1 body weight) between 15 June and 15 July, during the period of annual testicular quiescence.

Melatonin treatment was started in July in intact animals (group 2) and in December in ganglionectomized animals (group 4). The implants consisted of Silastic tubes (Dow Corning, medical grade, external diameter $1.96 \mathrm{~mm}$, interior diameter $1.47 \mathrm{~mm}$, length $50 \mathrm{~mm}$ ) filled with $50 \mathrm{mg}$ melatonin ( $\mathrm{N}$-acetyl 1-5-methoxytryptamine; Sigma Chemicals, St Louis, MO) and plugged with special glue (medical silicone, type A; Dow Corning, Midland, MI). Two tubes per animal were implanted s.c. in the dorsal region near the clavicle.

\section{Measurement of testicular activity}

Two variables were assessed for evaluation of testicular activity: testis volume $\left(\mathrm{cm}^{3}\right)$, indicating spermatogenetic activity, and plasma testosterone concentration (ng $\mathrm{ml}^{-1}$ ). The dimensions of the testis, length $(L)$, width $(W)$ and thickness $(T)$, were measured to the nearest $0.1 \mathrm{~mm}$ with callipers through the scrotum, and the formula $V=4 / 3 \times \pi \times L / 2 \times W / 2 \times T / 2$ was used to calculate testis volume (Setchell and Waites, 1964).
Testes were measured and blood was collected from the ear marginal vein between 09:00 and 11:00 h one day per month. The blood was centrifuged for $15 \mathrm{~min}$ at $1500 \mathrm{~g}$ and the plasma was stored at $-20^{\circ} \mathrm{C}$ until assayed.

Plasma testosterone was determined by radioimmunoassay using a commercial kit (Spectria Direct Testosterone, Orion, Espoo). Each plasma sample $(50 \mu \mathrm{l})$ was assayed in duplicate. Sensitivity, defined as the smallest quantity of hormone detectable, was $80 \mathrm{pg} \mathrm{ml}^{-1}$. The intra- and interassay coefficients of variation were $6.5 \%(n=15)$ and $7.8 \%(n=5)$, respectively.

\section{Statistical analysis}

Monthly mean values are presented \pm SEM. Within a given group, data were analysed by one-way ANOVA and Fisher's paired least significant difference (PLSD) test. A two-way ANOVA with repeated measures followed by a post-hoc Fisher's PLSD test were applied to compare groups. Differences between monthly values for the same group or between groups at a given time point were considered statistically significant if $P<0.05$.

\section{Results}

Testicular activity in control animals and animals with melatonin implants

Control animals (no implants, no surgery; Fig. 1) had no testicular activity at the start of the experiment (July). The first signs of testicular activity were detected in SeptemberOctober when testis volume (Fig. 1a) and plasma testosterone (Fig. 1b) increased significantly (plasma testosterone: October $2.41 \pm 0.30 \mathrm{ng} \mathrm{ml}^{-1}$ versus August $1.21 \pm 0.17$ ng $\left.\mathrm{ml}^{-1}, P<0.05\right)$. Testis volume and plasma testosterone peaked in November-December (plasma testosterone concentration $8.42 \pm 0.82 \mathrm{ng} \mathrm{ml}^{-1}$ ) and decreased markedly in January, reaching values indicating inactivity from February $\left(1.87 \pm 0.14 \mathrm{ng} \mathrm{ml}^{-1}\right)$. Testis volume did not reach a minimum until March, but the annual cycle was similar.

Melatonin implants were inserted in July, during the period of sexual quiescence. Testicular activity began at the same time (September-October) in animals with implants as in those of the control group, but maximum values were recorded from December until March for animals with implants; and testicular activity reached a minimum in April (plasma testosterone: March $4.30 \pm 0.29 \mathrm{ng} \mathrm{ml}^{-1}$ versus April $\left.1.23 \pm 0.12 \mathrm{ng} \mathrm{ml}^{-1}, P<0.001\right), 2$ months later than in the control group. Plasma testosterone concentrations were significantly higher $(P<0.001)$ in animals with melatonin implants than in controls from January to March and testis volume was greater $(P<0.001)$ in animals with implants from February to April.

\section{Testicular activity in ganglionectomized animals} without and with melatonin implants

In ganglionectomized animals without melatonin implants (Fig. 2), no seasonal variation in testicular activity 

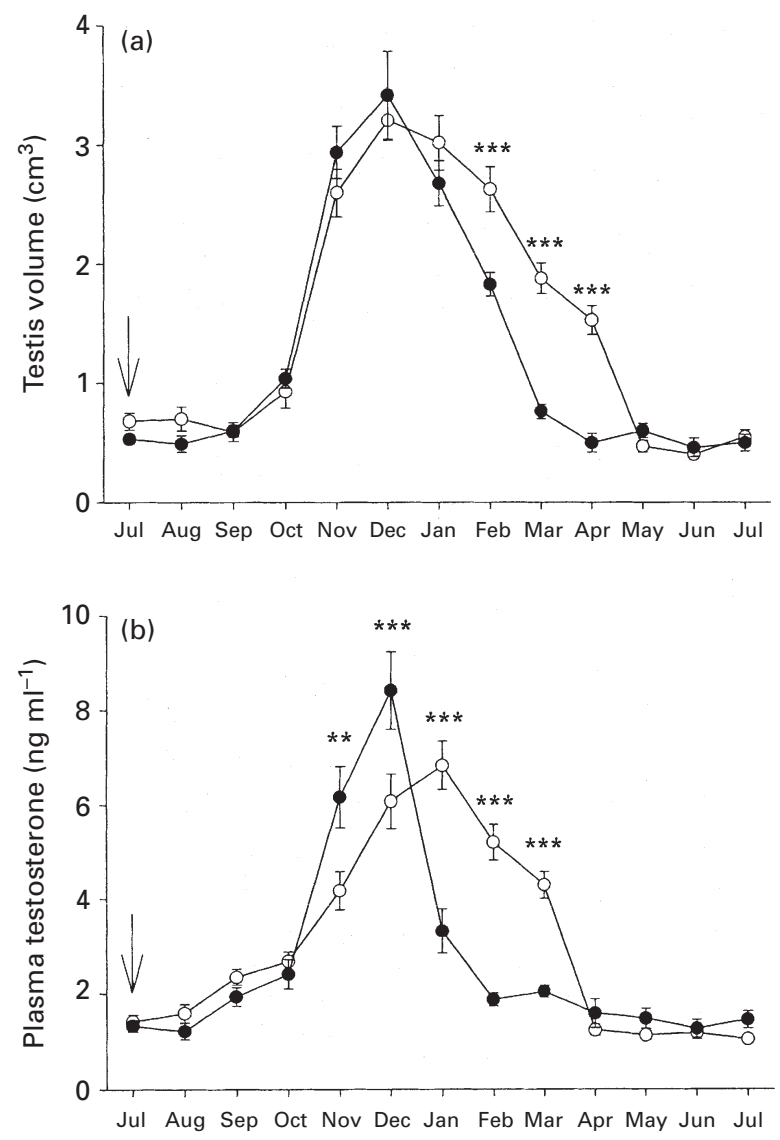

Fig. 1. Effects of subcutaneous melatonin implants on testicular activity in intact wild rabbits with $(\bigcirc)$ or without (control, melatonin implants. The arrow indicates the time of melatonin implantation. ${ }^{* *} P<0.01,{ }^{* * *} P<0.001$, animals with melatonin implants versus controls, for the same month.

was observed during the experiment. The annual mean for plasma testosterone was $1.60 \pm 0.4 \mathrm{ng} \mathrm{ml}^{-1}$ (minimum value: $1.45 \pm 0.22 \mathrm{ng} \mathrm{ml}^{-1}$; maximum value: $1.79 \pm$ $0.24 \mathrm{ng} \mathrm{ml}^{-1}$ ) (Fig. 2a) and for testis volume was $0.54 \pm 0.02 \mathrm{~cm}^{3}$ (minimum value: $0.46 \pm 0.05 \mathrm{~cm}^{3}$; maximum value: $0.62 \pm 0.10 \mathrm{~cm}^{3}$ ) (Fig. $2 \mathrm{~b}$ ), corresponding to testicular inactivity. Melatonin implants were inserted in December (when testicular activity was at a maximum in the control group). Testicular function was reactivated 2 months after melatonin implantation in ganglionectomized animals receiving implants, reaching a maximum in March and April (plasma testosterone: March $4.67 \pm 0.36 \mathrm{ng} \mathrm{ml}^{-1}$; April $\left.3.46 \pm 0.31 \mathrm{ng} \mathrm{ml}^{-1}\right)$ and decreasing significantly in May $\left(1.65 \pm 0.24 \mathrm{ng} \mathrm{ml}^{-1}, P<0.001\right)$. As in intact animals with melatonin implants, plasma testosterone decreased more rapidly than testis volume in ganglionectomized animals with melatonin implants. The testis volume of ganglionectomized animals with melatonin implants reached a minimum in July $\left(0.85 \pm 0.10 \mathrm{~cm}^{3}\right)$ and was $2.51 \pm 0.19 \mathrm{~cm}^{3}$ in May and $2.02+0.18 \mathrm{~cm}^{3}$ in June (June versus July, $P<0.001$ ).
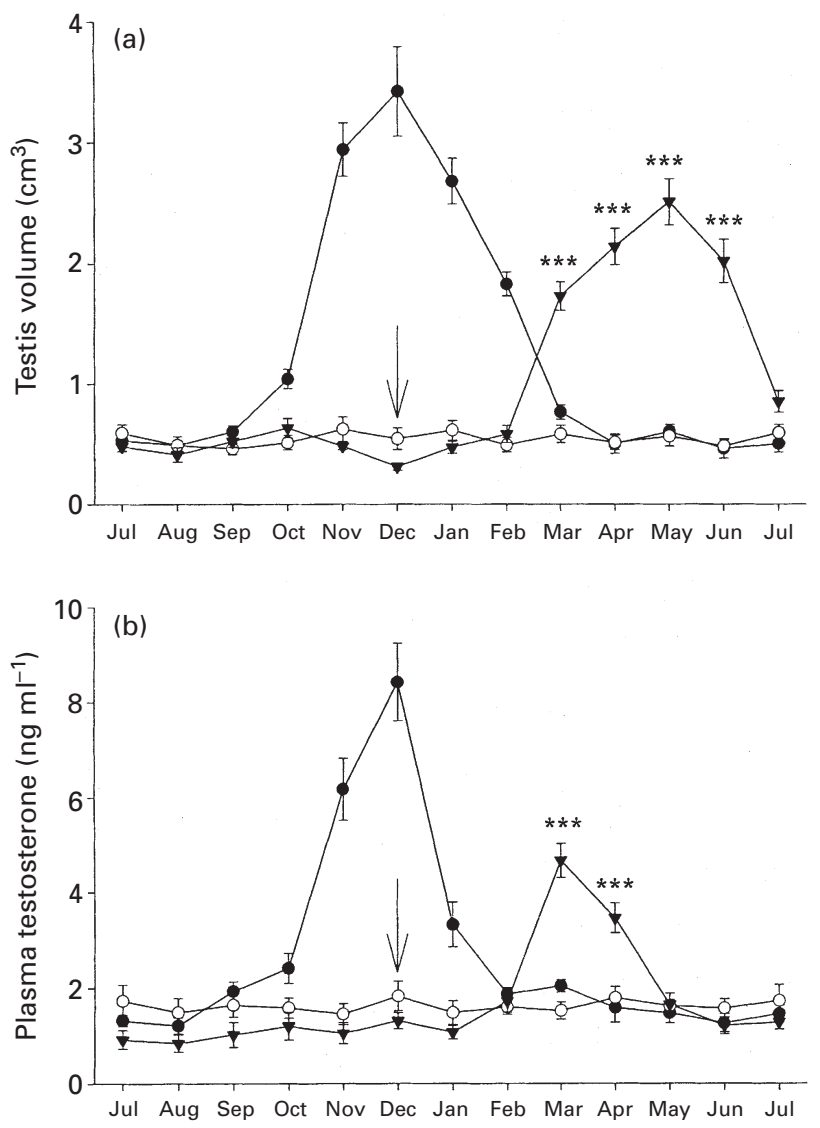

Fig. 2. Long-term effects of ganglionectomy and subcutaneous melatonin implants on testicular activity in wild rabbits: controls $(\bullet)$; ganglionectomized animals $(\bigcirc)$; ganglionectomized animals with melatonin implants $(\boldsymbol{\nabla})$. The arrow indicates the time of melatonin implantation. ${ }^{* * *} P<0.001$, ganglionectomized animals with melatonin implants versus ganglionectomized animals without implants, for the same month.

\section{Discussion}

The results of this study confirm that in wild rabbits from Zembra Island reared under natural temperature and photoperiod conditions, testicular activity is seasonal and increases in autumn, as demonstrated for this population by Ben Saad and Baylé (1985). Experimental exposure to short days ( $8 \mathrm{~h}$ light:16 $\mathrm{h}$ dark) at the beginning of summer induces reactivation of gonadal activity in this species (Ben Saad, 1997), demonstrating that this island population of wild rabbits is a short-day species. After bilateral superior cervical ganglionectomy, gonadal activity was not stimulated by the natural shortening of day length after the autumn equinox and no testicular activity was observed during the 13 months of the experiment, as shown in this species after optic nerve section. The lack of a testicular cycle under constant photoperiod conditions (Ben Saad, 1998) or when the seasonal melatonin signal was abolished for more than 1 year (present study) demonstrates that in this species the seasonal rhythm in reproduction is 
not self-sustained. Since Pengelley and Fisher (1957, 1963) first provided evidence of circannual rhythms in body weight, hibernation and daily food consumption in a mammal, the golden-mantled ground squirrel, numerous studies have provided evidence for circannual rhythms in body weight, locomotor activity, hibernation, moulting, food consumption and reproduction in birds and mammals (reviewed in Gwinner, 1986; Boissin and Canguilhem, 1988). In stable conditions (constant light or darkness, pinealectomy or ganglionectomy, constant short-day or long-day regimen), some species show a true circannual rhythm that may persist over many years. These endogenous annual rhythms, demonstrated in various species including ground squirrels (Pengelley and Fisher, 1963; Zucker et al., 1983), ferrets (Boissin-Agasse et al., 1985), sheep (Karsch et al., 1991) and European hamsters (Masson-Pévet et al., 1994; Saboureau et al., 1999), have been called type II annual rhythms. Rhythms that are not self-sustained have also been described and are called type I annual rhythms (Zucker et al., 1991; Gorman and Zucker, 1998). The wild rabbits of Zembra Island show a type I annual rhythm, similar to that demonstrated for other species such as Siberian and Syrian hamsters, spotted skunk, white-footed mice (reviewed in Zucker et al., 1991) and mink, another short-day species studied by our group, after superior cervical ganglionectomy, suprachiasmatic nucleus lesion or pinealectomy (Boissin-Agasse et al., 1988; Maurel et al., 1991, 1992b).

The lack of testicular stimulation and the reactivation of gonadal function after subcutaneous melatonin implantation in ganglionectomized rabbits and the greater duration of testicular activity in intact animals with melatonin implants (as also observed in another short-day mammal, mink; Maurel et al., 1992b) confirm that the pineal gland and melatonin are involved in the seasonal control of reproduction in this species. It was not possible to determine plasma melatonin or urinary 6-sulfatoxymelatonin concentrations in this species in these conditions. However, similar implants used in similar conditions in mink after superior cervical ganglionectomy (three implants per animal, mean body weight $1500 \mathrm{~g}$ ) (Maurel et al., 1992a,b, 1997) and in rats after pinealectomy (one implant per animal, mean body weight 500 g) (Kosa et al., in press) gave plasma melatonin (rats) and urinary 6-sulfatoxymelatonin (mink) concentrations similar to the highest nocturnal values measured in control animals. These high concentrations remained stable for more than 3 months in mink and 1 month in rats. It has been shown that the continuous release of melatonin by subcutaneous implants or intrahypothalamic microimplants, without daily rhythmicity (as achieved with an osmotic pump or daily injection or ingestion of melatonin), induces gonadal stimulation, as observed in intact animals reared under natural or experimental photoperiodic stimulation. This stimulatory effect has been measured not only at the testis (testis volume, plasma testosterone) but by the reinduction of pulsatile secretion of $\mathrm{LH}$ in various animals such as rams (Webster et al., 1991), fallow deer (Asher and
Peterson, 1991), ewes (Malpaux et al., 1993, 1997) and mink (Maurel et al., 1997). The most important characteristic of the melatonin signal is not circadian rhythmicity but the duration of nightly release (that is, the peak duration of melatonin), resulting in internal coincidence between sustained high concentrations of melatonin and an internal rhythm of sensitivity of the gonadotrophic axis to melatonin (Arendt et al., 1987; Bonnefond et al., 1990; Karp et al., 1991) through diurnal variation in melatonin binding sites. Indeed, a diurnal rhythm in melatonin binding sites has been demonstrated in the suprachiasmatic nucleus and the pars tuberalis (Laitinen et al., 1989; Gauer et al., 1993). Melatonin receptors may be modulated by melatonin (Gauer et al., 1993), but light exposure in pinealectomized rats during the dark period induces an increase in melatonin receptor density in the suprachiasmatic nucleus through serotonergic modulation (Masson-Pévet et al., 1996; Recio et al., 1996).

Melatonin implants triggered testicular activity in ganglionectomized rabbits but did not cause seasonal advance in intact rabbits because the triggering of testicular activity was similar in intact rabbits with implants and in controls. Thus, significant testicular reactivation was observed in October, 3 months after melatonin implantation (July). A similar latency in testicular activity (testis volume and plasma testosterone concentration) has also been observed in mink, in which significant testicular reactivation is observed after 3 months, whereas hypothalamic GnRH concentrations increase significantly after only 2 weeks and LH pulsatility parameters 1 month after melatonin implantation in ganglionectomized animals (Maurel et al., 1997). Such a cascade of events, with latencies between the different steps of the $\mathrm{GnRH}$ axis (increase in hypothalamic LHRH, stimulation of pituitary LH release, renewal of testicular activity) as demonstrated in mink, may account for the 3 month delay in testicular activation after subcutaneous melatonin implantation in these species. Melatonin replacement in spring (April-May) rather than summer (July) might have led, with a similar delay in reactivation, to an earlier start to the breeding season. Such an experiment was not performed and in the conditions used in this study no such advance in the breeding period was demonstrated. However, the possibility that such an advance might occur in other conditions cannot be ruled out.

In rabbits with melatonin implants, the duration of the breeding season was longer in intact than in ganglionectomized animals: 1 month on the basis of testis volume and 3 months on the basis of plasma testosterone concentrations. This may be due to the timing of melatonin implant insertion, inducing reactivation of the $\mathrm{GnRH}$ axis in a different season. Indeed, reactivation occurred in spring and early summer in ganglionectomized animals implanted in December and in autumn-early spring in intact animals implanted in July. This difference in response might be due to seasonal variation in the sensitivity of melatonin receptors with large decrease in the number or sensitivity of these receptors in late spring and summer. 
The breeding season may be longer in intact animals with melatonin implants than in non-implanted animals for a combination of reasons: (i) high melatonin concentrations supplied by the implants in February-April, when nocturnal concentrations of endogenous melatonin are decreasing due to increasing day length; and (ii) the presence of a large number of receptors or high sensitivity of the receptors during this part of the year, assuming, as suggested above, that there is a seasonal decrease in late spring and summer.

The results of the present study show that melatonin exerts a stimulatory effect on the gonadal axis in rabbits. For the wild European rabbit (Oryctolagus cuniculus), studies conducted in England and in France have characterized the female and male reproductive cycles (Flux, 1965; Arthur, 1980; Boyd, 1985; Boyd and Myhill, 1987; Dubry, 1987). Maximum testicular activity occurs from January to June-July after which it decreases and there is a period of rest from sexual activity from October to December. Gravid females are observed only from February to August. Thus, the wild European rabbit appears to be a long-day breeder, the sexual activity of which is inhibited by short days. This was demonstrated experimentally by Boyd (1985), who showed that transfer from long (16 h light:8 h dark) to short ( $8 \mathrm{~h}$ light:16 h dark) days or the insertion of subcutaneous melatonin implants in rabbits maintained in long days caused testicular regression. The opposite result was obtained in the present study: the wild rabbit population of Zembra Island breeds in short-day conditions and its reproductive activation is controlled by short days and melatonin. It is difficult to explain this difference in terms of temperature and photoperiod, because these are the same for the wild rabbit populations of southern France and Zembra Island (north Tunisia). This difference in the photoperiodic control of gonadal activity in these two populations may be due to the insularity of the rabbit population of Zembra Island. Indeed, as demonstrated for other populations, the geographical isolation of a given species may lead to: (i) changes in body size, such as gigantism in small mammals (Lomolino, 1985; Libois et al, 1993); (ii) changes in litter size, such as the decrease in fecundity observed in the shrew Crocidura suaveolens on Corsica (Fons et al., 1997), Rattus rattus on various Mediterranean islands (Cheylan, 1986) and the multimammate rat Mastomys erythroleucus on La Madeleine island, Senegal, Africa (Granjon, 1987); (iii) a delay in sexual maturity, as observed for Rattus rattus on Corsica (Granjon and Cheylan, 1988). For a species colonizing an island, the syndrome d'insularité ('isolation syndrome'), as defined by Blondel (1995), concerns new environmental conditions including, for example, variations in population density due to changes in the diversity of predators or competitors or their disappearance, changes in nutritional conditions and changes in opportunities for burrowing. As shown by Heideman and Bronson (1991) and Heideman et al. (1999), even within a single population there may be individuals that range from completely non-responsive to completely responsive to photoperiod. Arthur (1980) studied continental populations of wild rabbits and found that although testicular activity is low for most animals in winter, some males are sexually active at this time of the year. Similarly, population heterogeneity has been demonstrated in the regulation of testicular function in populations of Arvicanthis niloticus from Mali and Burkina Faso, Africa (Sicard et al., 1992) and in the sahelian multimammate rat, Mastomys erythroleucus, in Mali, Africa (Sicard and Fuminier, 1996).

When the rabbits were introduced to the island of Zembra, it is possible that only animals reproducing in winter were able to reproduce successfully due to the specific conditions of isolation. This would have led to the disappearance of animals reproducing in spring, corresponding to most of the population. No underground burrows were found for the wild rabbits of Zembra. In contrast, continental populations of wild rabbits excavate underground burrows to protect their young against predators and adverse climatic conditions during the first few weeks of lactation. Although the soil of the island is suitable for burrowing, wild rabbits do not excavate (Arnould and Dollé, 1954). This specific behaviour may have played a role in the disappearance of the young of females that gave birth late in the season. Specific pressures, such as seasonal predation, may have resulted in the survival of only those litters born early. This isolated population, with a pattern of photoperiodic gonadal stimulation opposite to that observed in continental populations, may be an illustration of the process of genetic adaptation. During abrupt changes in environment, such as those that occur during colonization of an island or during the creation of an environmental islet within a biotope (for example as part of the desertification process, resulting in the creation of small islets of vegetation isolating fragments of animal populations), the survival of a population depends on individuals with reproductive characteristics that rendered them marginal in the old environmental conditions. These individuals become the principal reproducers in the new environment, enabling the species to survive. This plasticity of the species, enabling it to survive abrupt environmental changes and to colonize new biotopes, is made possible by heterogeneity within a given population.

\section{References}

Arendt J (1986) Role of the pineal gland and melatonin in seasonal reproductive function in mammals Oxford Reviews of Reproductive Biology 8 263-320

Arendt J, Symons AM, English J and Poulton AL (1987) Melatonin and seasonal breeding cycle in sheep. In Advances in Pineal Research pp 135-139 Eds RJ Reiter and F Fraschini. John Libbey, London

Arendt J, Symons AM, English J, Poulton AL and Tobler I (1988) How does melatonin control seasonal reproductive cycles Reproduction, Nutrition and Development 28 387-398

Arnould M and Dollé JE (1954) Sur la présence d'un niveau fossilifère oligocène dans l'ile de Zembra Mémoires de la Société des Sciences Naturelles de Tunisie 2 65-71

Arthur CP (1980) Démographie du lapin de garenne Oryctolagus cunicu- 
lus (L) 1758 en région parisienne Bulletin Mensuel de l'Office National de la Chasse No. Sp Sci Tech, December 127-162

Asher GW and Peterson AJ (1991) Pattern of LH and testosterone secretion of adult male fallow deer (Dama dama) during the transition into the breeding season Journal of Reproduction and Fertility 91 649-654

Ben Saad MM (1997) Activité testiculaire chez Oryctolagus cuniculus, lapin sauvage de l'île de Zembra (Tunisie), en jours courts et en jours longs. Effet de la désafférentation de la pinéale Archives of Physiology and Biochemistry 105 71-77

Ben Saad MM (1998) Variations saisonnières de la thyroxinémie et de la testostéronémie chez le lapin sauvage de l'île de Zembra (Orychtolagus cuniculus). Déterminisme du cycle annuel de reproduction Thèse Doctorat, Université de Tunis, Tunisie

Ben Saad M and Baylé JD (1985) Seasonal changes in plasma testosterone, thyroxine and cortisol levels in wild rabbits (Oryctolagus cuniculus algirus) of Zembra island General and Comparative Endocrinology 57 $383-388$

Blondel J (1995) Biogéographie - Approche Ecologique et Evolutive Collection Ecologie 27 p. 297, Masson, Paris

Boissin J and Canguilhem B (1988) Les rythmes circannuels chez les Mammifères Archives Internationales de Physiologie et de Biochimie 96 A289-A345

Boissin-Agasse L, Richard P and Boissin J (1985) Activité testiculaire du furet maintenu pendant plus de 4 ans en lumière permanente et température constante Comptes Rendus Hebdomadaires de l'Académie des Sciences Paris 300 685-690

Boissin-Agasse L, Jacquet JM, Lacroix A and Boissin J (1988) Long-term effects of pinealectomy on testicular function, luteinizing hormonereleasing hormone hypothalamic system, and plasma prolactin levels in the mink, a short-day breeder Journal of Pineal Research 5 385-396

Bonnefond C, Martinet L and Monnerie R (1990) Effects of timed melatonin infusions and lesions of the suprachiasmatic nuclei on prolactin and progesterone secretions in pregnant or pseudopregnant mink (Mustela vison) Journal of Neuroendocrinology 2 583-591

Boyd IL (1985) Effect of photoperiod and melatonin on testis development and regression in wild European rabbits (Oryctolagus cuniculus) Biology of Reproduction 33 21-29

Boyd IL and Myhill DG (1987) Seasonal changes in condition, reproduction and fecundity in the wild European rabbits (Oryctolagus cuniculus) Journal of Zoology, London 212 223-233

Carter DS, Hall VD, Tamarkin BD and Goldman BD (1982) Pineal is required for testicular maintenance in the Turkish hamster (Mesocricetus brandti) Endocrinology 111 863-871

Cheylan G (1986) Facteurs historiques, écologiques et génétiques de l'évolution des populations méditerranéennes de Rattus rattus (L). Discussion des modèles de spéciation PhD Thesis, University of Montpellier

Dubry D (1987) Le lapin de garenne Oryctolagus cuniculus. In Les Mammifères de Corse pp 121-125 Parc Naturel Régional de la Corse, Ajaccio

Flux JEC (1965) Timing of the breeding season in the hare Lepus europaeus Pallas and rabbit Oryctolagus cuniculus (L) Mammalia 29 557-562

Fons R, Poitevin F, Catalan J and Croset H (1997) Decrease in litter size in the shrew Crocidura suaveolens (Mammalia, Insectivora) from Corsica (France): evolutionary response to insularity? Canadian Journal of Zoology 75 954-958

Gauer F, Masson-Pévet M, Skene DJ, Vivien-Roels B and Pévet P (1993) Daily rhythm of melatonin binding sites in the rat pars tuberalis and suprachiasmatic nuclei; evidence for a regulation of melatonin receptors by melatonin itself Neuroendocrinology 57 120-126

Goldman BD (1999) The circadian timing system and reproduction in mammals Steroids 64 679-685

Goldman BD and Darrow JM (1983) The pineal gland and mammalian photoperiodism Neuroendocrinology 37 386-396

Gorman MR and Zucker I (1998) Mammalian seasonal rhythms: new perspectives gained from the use of simulated natural photoperiods. In Biological Clocks: Mechanisms and Applications pp 195-204 Ed. Y Touitou. Elsevier, Amsterdam
Granjon L (1987) Evolution allopatrique chez les muridés: mécanismes éco-éthologiques liés au syndrome d'insularité PhD Thesis, University of Montpellier

Granjon L and Cheylan G (1988) Mécanismes de coexistence dans une guilde de Muridés insulaires (Rattus rattus, L, Apodemus sylvaticus L et Mus musculus domesticus Rutty) en Corse: conséquences évolutives Zeitschrift für Säugetierkunde 53 301-316

Gwinner E (1986) Circannual Rhythms Springer Verlag, Berlin Heidelberg New York

Heideman PD and Bronson FH (1991) Characteristics of a genetic polymorphism for reproductive photoresponsiveness in the white footed mouse (Peromyscus leucopus) Biology of Reproduction 44 1189-1196

Heideman PD, Kane SL and Goodnight AL (1999) Difference in hypothalamic 2-[125I]iodomelatonin binding in photoresponsive and nonphotoresponsive white footed mice, Peromyscus leucopus. Brain Research 840 56-64

Hoffmann K (1981) Pineal involvment in the photoperiodic control of reproduction and other functions in the Djungarian hamster Phodopus sungorus. In The Pineal Gland Vol. II Reproductive Effects pp 83-102 Ed. RJ Reiter. CRC Press, Boca Raton, FL

Karsch FJ, Woodfill CJI, Malpaux B, Robinson JE and Wayne NL (1991) Melatonin and mammalian photoperiodism: synchronization of annual reproductive cycles. In The Suprachiasmatic Nucleus: The Mind's Clock pp 217-232 Eds DC Klein, RY Moore and SM Reppert. Oxford University Press, New York

Karp JD, Hastings MH and Powers JB (1991) Melatonin and the coding of day length in male Syrian hamster Journal of Pineal Research $\mathbf{1 0}$ 210-217

Kennaway DJ (1984) Pineal function in ungulates Pineal Research Review 2 113-134

Kosa E, Maurel D and Siaud P Pinealectomy decreases glucagon responsiveness to glucose variations in rats Physiological Research (in press)

Laitinen JT, Castren E, Vakkuri O and Saavedra JM (1989) Diurnal rhythm of melatonin binding in the rat suprachiasmatic nucleus Endocrinology 124 1585-1587

Libois R, Fons R and Bordenave D (1993) Mediterranean small mammals and insular syndrome: biometrical study of the long-tailed field mouse (Apodemus sylvaticus) (Rodentia-Muridae) of Corsica Bonner Zoologische Beiträger 44 147-163

Lincoln GA (1979) Photoperiodic control of seasonal breeding in the ram: participation of the cranial sympathetic nervous system Journal of Endocrinology 82 135-147

Lomolino MV (1985) Body size of mammals on islands: the island rule re-examined American Naturalist 125 310-316

Maeda KL, Mori Y and Kano Y (1985) Superior cervical ganglionectomy prevents gonadal regression and increased plasma prolactin concentrations induced by long days in goats Journal of Endocrinology 110 137-144

Malpaux B, Daveau A, Maurice F, Gayrard V and Thiery JC (1993) Shortday effects of melatonin on luteinizing hormone secretion in the ewe: evidence for central sites of action in the mediobasal hypothalamus Biology of Reproduction 48 752-760

Malpaux B, Viguié C, Skinner DC, Thiery JC and Chemineau P (1997) Control of the circannual rhythm of reproduction by melatonin in the ewe Brain Research Bulletin 44 431-438

Masson-Pévet M, Naimi F, Canguilhem B, Saboureau M, Bonn D and Pévet $\mathbf{P}$ (1994) Are the annual reproductive and body weight rhythms in the male European hamster (Cricetus cricetus) dependent upon a photoperiodically entrained circannual clock? Journal of Pineal Research 17 151-163

Masson-Pévet M, Bianchi L and Pévet P (1996) Circadian photic regulation of melatonin receptor density in the rat suprachiasmatic nuclei: comparison with light induction of fos-related protein Journal of Neuroscience Resarch 43 632-637

Maurel D, Saboureau M, Roch G and Boissin J (1990) Effets de la désafférentation de la glande pinéale par ablation bilatérale des ganglions sympathiques cervicaux supérieurs sur la reprise automnale de l'activité testiculaire chez le Vison Comptes Rendus Hebdomadaires de I'Académie des Sciences Paris 310 245-251 
Maurel D, Boissin-Agasse L, Roch G, Herbuté S and Boissin J (1991) Suprachiasmatic nucleus lesions abolish photoperiod-induced changes in the testis function and $\mathrm{GnRH}$ immunoreactivity in the mink, a shortday breeder Neuroendocrinology 54 103-110

Maurel D, Mas N, Roch G, Boissin J and Arendt J (1992a) Diurnal variations of urinary 6-sulphatoxymelatonin in male intact or ganglionectomized mink Journal of Pineal Research 13 117-123

Maurel D, Boissin-Agasse L, Roch G and Boissin J (1992b) Short-day stimulation of testicular activity and immunoreactivity of the hypothalamic GnRH system in mink following deafferentation of the pineal body by bilateral superior cervical ganglionectomy and melatonin replacement Brain Research 578 99-106

Maurel D, Jallageas M, Mas N, Gautron JP and Roch G (1997) Effects of superior cervical ganglionectomy and melatonin replacement on intrahypothalamic LHRH content and pulsatile luteinizing hormone release in the mink Biological Rhythm Research 28 198-215

Pengelley ET and Fisher KC (1957) Onset and cessation of hibernation under constant temperature and light in the golden-mantled ground squirrel, Citellus lateralis. Nature 180 1371-1372

Pengelley ET and Fisher KC (1963) The effect of temperature and photoperiod on the yearly hibernating behavior of captive golden-mantled ground squirrels (Citellus lateralis tescorum) Canadian Journal of Zoology 41 1103-1120

Ravault JP, Martinet L, Bonnefond C, Claustrat B and Brun J (1986) Diurnal variations of plasma melatonin concentrations in pregnant or pseudopregnant mink (Mustela vison) maintained under different photoperiods Journal of Pineal Research 3 365-373

Recio J, Pévet P and Masson-Pévet M (1996) Serotonin modulation of photically induced increase in melatonin receptor density and fos immunoreactivity in the suprachiasmatic nuclei of the rat Journal of Neuroendocrinology 8 839-845

Reiter RJ (1972) Evidence for refractoriness of the pituitary-gonadal axis to the pineal gland in golden hamsters and its implications in annual reproductive rhythms Anatomical Record 173 365-372

Reiter RJ (1974) Circannual reproductive rhythms in mammals related to photoperiod and pineal function: a review Chronobiologia 1 365-395

Reiter RJ (1980) The pineal and its hormones in the control of the reproduction in mammals Endocrine Review 1 109-131
Reiter RJ (1986) Annual cycle of reproduction in mammals: adaptive mechanisms involving the photoperiod and the pineal gland. In Endocrine Regulations as Adaptive Mechanisms to the Environment pp 161-170 Eds I Assenmacher and J Boissin. Les Presses du CNRS, Paris

Reiter RJ (1988) Comparative aspects of pineal melatonin rhythms in mammals Animal and Plant Sciences 1 111-116

Saboureau M, Masson-Pévet M, Canguilhem B and Pévet P (1999) Circannual reproductive rhythm in the European hamster (Cricetus cricetus): demonstration of the existence of an annual phase of sensitivity to short photoperiod Journal of Pineal Research 26 9-16

Setchell BP and Waites GMH (1964) Blood flow and the uptake of glucose and oxygen in the testis and epididymys of the ram Journal of Physiology London 171 411-425

Sicard B and Fuminier F (1996) Environmental cues and seasonal breeding patterns in Sahelian rodents Mammalia 60 667-675

Sicard B, Maurel D, Fuminier F and Boissin J (1992) Circadian rhythm of photosensitivity and the adaptation of reproductive function to the environment in two populations of Arvicanthis niloticus from Mali and Burkina Faso Journal of Reproduction and Fertility 95 159-165

Stetson MH and Watson-Whitmyre M (1976) Nucleus suprachiasmaticus: the biological clock in the hamster? Science 191 197-199

Webster JR, Suttie JM, Veenvliet BA, Manley TR and Littlejohn RP (1991) Effects of melatonin implants on secretion of luteinizing hormone in intact and castrated rams Journal of Reproduction and Fertility 92 21-31

Zucker I, Boshes M and Dark J (1983) Suprachiasmatic nuclei influence circannual and circadian rhythms of ground squirrels American Journal of Physiology 244 R472-R480

Zucker I, Lee TM and Dark J (1991) The suprachiasmatic nucleus and annual rhythms of mammals. In The Suprachiasmatic Nucleus: The Mind's Clock pp 246-259 Eds DC Klein, RY Moore and SM Reppert. Oxford University Press, New York

Received 14 April 2000.

Accepted 7 September 2000. 